\title{
Historic Masonry Walls Strengthened with GFRP Strips Under Compression and Shear
}

\author{
R Capozucca* and E Magagnini \\ Marche Polytechnic University, Ancona, Italy
}

*Corresponding author: R Capozucca, Marche Polytechnic University, Ancona, Italy.

Received Date: May 01, 2019

Published Date: May 20, 2019

\section{Short Communication}
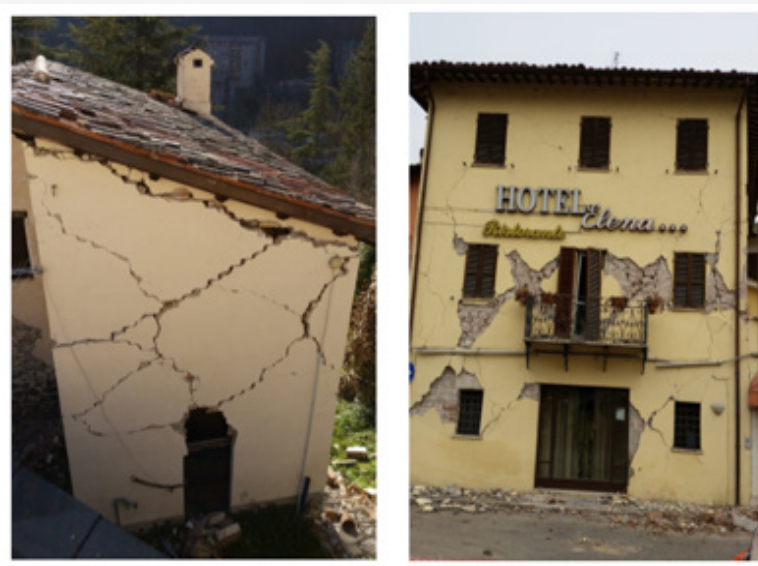

Figure 1: Damage of historic masonry walls under shear loading during earthquake October 2016 (Visso, Marche region, Italy).

A large portion of the European cultural heritage is made of masonry buildings that have a growing economic and social value in many countries. Therefore, their preservation is considered an important issue in modern societies both for their historical interest and for the economic contribution in contexts where tourism has become a major industry. During past and recent earthquakes these historic buildings have demonstrated to be particularly prone to damage, showing partial or total collapse. In many cases, this was due to restorations non-respectful of the original structural layout. In particular, after last earthquakes of 2016 and 2017 that invested a large area of Appennini mountains in the centre of Italy where many historic towns are located, a duty that regards mostly structural engineers is the preservation of cultural architectural heritage. In recent years there has been increasing interest in loadbearing walls, in particular, the knowledge how historic masonry walls behaves under seismic action is fundamental for preserving the building patrimony. In an actual masonry structure, during seismic action, the presence of shear stress both in the brick and mortar will give rise to diagonal tension and compression in the masonry as a whole. Loss of strength of masonry cross walls after cracking diagonal damages (Figure 1) due to shear loads often leads to the ruin of walls and consequently to entire building. Knowledge regarding the behaviour of masonry walls under seismic action is, without doubt, the basis for preserving both monumental historic masonry buildings and/or minor masonry buildings. Because of their nature and history, structures of historic buildings present a number of typical, practical aspects that limit the application of modern codes and building standards (Figure 1).

Firstly, the material of brick and/or stone as even mortar are in general characterized by mechanical parameters different from material of modern masonry walls; secondary, the shear strength of unreinforced masonry is mostly conditioned by the weak mortar of joints. Although many experimental works over the last decades, even adopting different scale models, and theoretical modelling analysis have been carried out, still requires investigation. Following the topic of the preservation of the existing structures, in recent years, the rehabilitation and strengthening of unreinforced masonry has seen remarkable development on the basis of new techniques and materials. During the last decade, the use of composites - fibre reinforced polymers (FRPs) - for the strengthening of the historic unreinforced masonry has increased rapidly. Among the new reinforcement strategy, the use of FRP system, more specifically, present a number of advantages over traditional materials due to their high tensile strength, low specific weight and excellent resistance against aggressive environmental actions. It is emphasized that the choice of strengthening the FRP material should avoid any incompatibility, physical or chemical, with the existing masonry. Usually, externally bonded (EB) FRP strips/ sheets are adopted as a technique for the strengthening of shear masonry walls by increasing tensile capacity for supporting combined compression and shear actions under earthquakes, 
giving a tensile capacity to historic masonry that it is normally weak to tensile stress. In Italy a Code of Practice for practitioners was edited to serve as a guideline for FRPs use in the strengthening of masonry structures that supplies formulas and suggestions. Experimental analysis of masonry walls, strengthened using FRPs, has highlighted that such strengthening confers a greater capacity to undergo ample horizontal movements, dissipating energy through the progression of ample and widespread cracking.

In general, the experimental evidences available in the technical literature have shown that in a system composed by masonry and external bounded strengthening the following failure mechanisms can occur in combination: cracking of masonry in tension, crushing of masonry in compression, shear-sliding of masonry, failure of fibre-reinforced composites and, finally, delamination of FRP from masonry. Experimental tests indicate that the dangerous mechanism of brittle failure is due to delamination, especially if the FRP strips are glued to historic clay bricks with a weak clay surface. In particular, when delamination from the support occurs, the effectiveness of the reinforcement vanishes, and the entire system reaches brittle failure due to delamination mechanism before the strength capacity of composite materials or of the compressive strength of walls. Therefore, one of the most important aspects in the application of composite materials for strengthening structural elements is the adhesion between the reinforcing and reinforced materials. It has been considered that in the historic masonry walls invested by seismic actions the bond of FRP strips may be decrease both by damage due to cracking of masonry that compromise the tensile strength or by phenomenon of local delamination buckling of FRP strips subjected to alternate tensile-compression stresses. The strengthening of masonry walls with externally bounded FRPs reis opening new venues for theoretical and experimental research centering on the possible performance of masonry subjected to cyclic loading considering the behaviour under loading with or without cracking damage.

Another important task for the current structural engineer is the evaluation of the structural safety state of existing masonry buildings under actual or new loading condition. From this point of view, reliable numerical models are necessary to assess existing masonry structures. In fact, in the last decades, the scientific community has demonstrated great interest in the development of sophisticated numerical tools as an opposition to the tradition of rules- of-thumb or empirical formulae adopted to evaluate the safety of masonry buildings. In particular, nonlinear models implemented in suitable finite elements formulations currently represent the most common advanced strategy to simulate the structural behaviour of masonry structures (Figure 2). The problem of performing reliable analyses becomes even more important when a decision is required about the opportunity of repairing the construction and to design the strengthening. The main problem in the development of accurate stress analysis for masonry structures is the definition and the use of suitable material constitutive laws. The particular characteristics of the masonry material make difficult to adopting existing numerical tools from more advanced research field, like mechanics of concrete, rock and composite materials. From this point of view, it must be considered that the masonry is characterized by a typical softening behaviour, essentially due to the formation and growth of the cracks in the bricks and mortar joints. Indeed, masonry shows a softening behaviour not only in tension, but also in compression and in the case of shear stresses. In the nonlinear FE method, many computational problems, as localization and spurious mesh sensitivity, can arise from the presence of the strain softening. A further modelling trouble is associated to the simulation of FRPreinforcement behaviour, especially if it is glued on the masonry external surfaces. Indeed, the FRP strips behave as a linear-elastic material until a perfectly brittle failure occurs; some modelling difficulties can arise when the possible decohesion between the FRP and the masonry is considered. Furthermore, the modelling of the adhesion between FRPs and masonry with the dangerous mechanism of debonding or delamination is another aspect that requires investigation. Different approaches can be developed in order to reproduce the presence of the FRP strengthening and its possible decohesion. One of these requires the adoption of "special" elements (interface elements) which connect the nodes of the mesh of panel to the nodes of the FRP elements. Another strategy involves in a simplified manner, the use of "special" constitutive laws for FRP-strengthening elements with the assumption of perfect bond between FRP and masonry support (Figure 2).

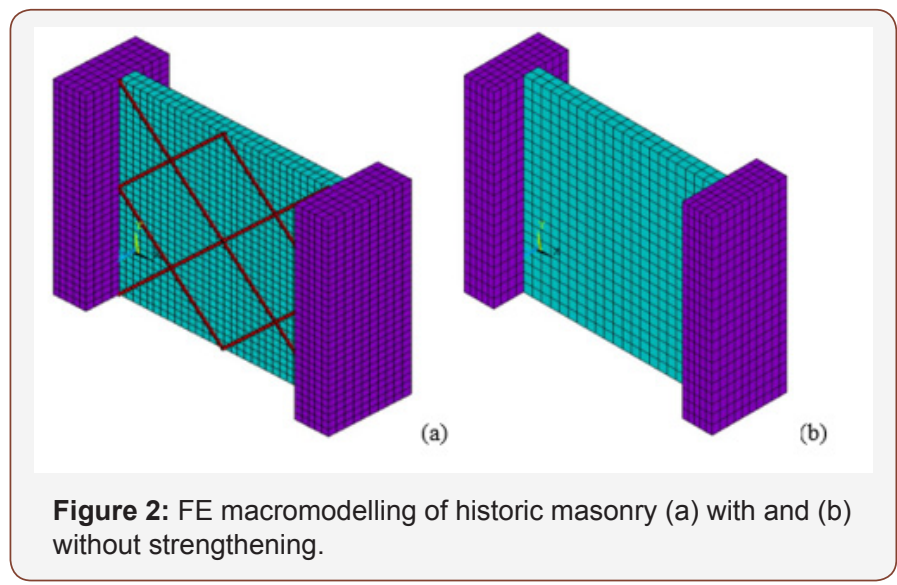

\section{Acknowledgment}

None.

\section{Conflict of Interest}

No conflict of interest.

\section{References}

1. Eluozo SN (2012) Mathematical Model to Predict Klebsiella Pneumonae Transport influenced by Porosity and Void Ratio in Shallow Aquifers. ARPN Journal of Earth Science 1(2).

2. Eluozo SN, Nwaoburu AO (2013) Mathematical Model to Monitor the deposition of Void ratio and Dispersion of Phosphorous Influenced in salmonella Growth Rate in Coarse and Gravel Formation in Borikiri, Rivers State of Nigeria. American Journal of Engineering Science and Technology Research 1(4): 59-67.

3. Eluozo SN, Nwaoburu AO (2013) Mathematical Model to Predict Adsorption Rate of Potassium Influenced by Permeability in Lateritic and Silty Formation in Coastal Area of Eagle Island, Port Harcourt, Niger Delta of Nigeria. International Journal Sustainable Energy and Environment 1(5): 111-119. 
4. Eluozo SN, Nwaoburu AO (2013) Modeling the Deposition Adsorption Rate of Carbon Influenced by Porosity in Semi Confined Bed in Okirika, Rivers State of Nigeria. International Journal of sustainable Energy and Environment 1(5): 103-110.

5. Engelbrecht JFP (1993) An assessment of health aspects of the impact of domestic and industrial waste disposal activities on groundwater resources, pp. 1-59.

6. Eluozo SN, Nwaoburu AO (2013) Mathematical Model to Predict the Migration of Cryptosporidium in Homogeneous Formation in ObioAkpor, Rivers State of Nigeria. International Journal Applied Chemical Science Research 1(6): 83-94.

7. Eluozo SN, Nwaoburu AO (2013) Modeling the Transport of Arsenic on Pore Fluid and Solid Surface in Heterogeneous Soil Formation, Niger Delta of Nigeria. World Journal of Science and Technology Research 6: 124-134.

8. Eluozo SN, Nwaoburu AO (2013) Mathematical Model to Predict Transient Flow Influenced by Compressible Fluid in Non-Homogeneous Anisotropic Aquifer in Deltaic Environment. Sjournals: Engineering Science and Technology, pp. 1-9.

9. Eluozo SN, Nwaoburu AO (2013) Mathematical Modeling and Simulation to Predict the transport of Diplococcic in Homogeneous Unconfined Aquifer in Port Harcourt Metropolis, Niger delta of Nigeria International Journal of Materials, Methods and Technology 1(5): 103-115.

10. Ghiores WC, Wilson JT (1988) Microbial ecology of the Terrestrial Subsurface. Advances in Applied Microbiology. Academic Press Inc 33: 107-172.
11. Engelbrecht JFP, Tredoux (2000) G bacteria in "unpolluted" groundwater Presented at the WISA 2000 Biennial Conference, Sun City, South Africa, pp. 2.

12. Eluozo SN, Ademiluyi JO (2013) Establishment of Porosity and Permeability Model Correlation to Validate E. coli Transport to Groundwater Aquifers; Rivers State of Nigeria. International Journal of Engineering and Technology, Science Publishing Corporation 2(1): $17-$ 24.

13. Eluozo SN (2013) Effect of formation characteristics on hydraulic conductivity in unconfined bed in Etche Rivers State of Nigeria: Scientific Journal of Pure and Applied Science 2(1).

14. Eluozo SN (2013) Dispersion influence from Void Ratio and Porosity on E. coli Transport in Homogeneous Formation in Coastal Area of Degema, Rivers State of Nigeria: Scientific Journal of Environmental Science 2(1): 10-18.

15. Eluozo SN, Ademiluyi JO, Nwaoburu AO (2011) Model Development Approach to Predict the Behaviour of E. coli Transport on Stationary Phase in Khana, Deltaic Environment of Rivers State, Nigeria. International Journal of Current Research 3(7): 140-145.

16. Eluozo SN, Nwaoburu AO (2013) Model Evaluation to Predict Nitrogen Depositions influenced by Porosity and Cadmium Inhibition in Coastal area of Port Harcourt. American Journal of Engineering Science and Technology Research 1(8): 128-140. 